\title{
Robin Lane Fox. The Classical World: an Epic History of Greece and Rome. (Penguin Books, London, 2006, pp. xvi \& 703)
}

\author{
by Garrett Barden
}

With Robin Lane Foxs (RLF) The Classical World (TCW) Penguin has, once more, given us an immensely valuable book that any one interested in the development of European Civilization should read.

TCW is a history of the Greek and Roman development of the Mediterranean world spanning nine hundred years from Homer (c. 750 BC; mercifully, RLF does not use the obscurantist and illogical $\mathrm{CE}$ and $\mathrm{BCE}$ ) with some account of the pre-Homeric world of his epics to the death of the Emperor Hadrian in the early years of the second century AD. In his Preface, RLF writes that he has not assumed a familiarity with the subject and that he has enjoyed the challenge of writing a history of nine hundred years. (TCW, xv) Readers will enjoy the challenge of reading what the author enjoyed the challenge of writing.

His dictis, it is not an easy book to review. History, acted forward, is written backwards. The historian knows in as much as the data to be understood exist, and are correctly understood what the actor could not have known. But the actors about whom the historian writes were, as we all are, historians who remembered, often quite inaccurately and inadequately, the past: Those who idealize the past tend not to understand it (TCW, 4) The actors looked forward, as we do, to a future that by their actions they hoped to bring about. Sometimes they brought it about; sometimes they did not. Whether or not what was brought about was what they had hoped, they could not know, as we cannot know, its consequences, the human world being in great measure the unintended consequences of intended action. RLF opens with a chapter with no number, and which stands outside the six parts into which the book is divided, on Hadrian and the Classical World. The Spaniard Hadrian respected the classical Greek and Roman past and, wherever he went, he visited great relics of it, but did he understand the context in which it had once belonged, how it had evolved and how his own rile as emperor had come about? (TCW, 6) RLF holds, uncontroversially I think, that he did not. TCW is an attempt to follow its (the classical worlds) highways as Hadrian, its great global traveler, never did. (TCW, 9) The first chapter suggests how the book is to be read; not simply to understand the best available historical opinion but, while reading, constantly to keep in mind that, however tentative our understanding may be and open to more or less substantial revision (it were absurd to suppose that everything now held is utterly mistaken), we grasp not alone what the actors did not, but what they could not, grasp. The final sentence in the final chapter, which, like the first, stands outside the six parts, and has no number, Hadrian: A Retrospective, obliquely reminds the reader of this: But he had no idea that the Christians, whose harassment he regulated, would then overturn this world by antiquitys greatest realignment of freedom and justice: the 
underworld would no longer be a garden designers fancy. (TCW, 606)

Between the first chapter and the last are six parts with 55 chapters all told: The Archaic Greek World, The Classical Greek World, Hellenistic Worlds, The Roman Republic, From Republic to Empire, and finally, An Imperial World. What during the nine hundred years was going forward was the turbulent, uncertain, and in prospect unknown development of what became the Roman Mediterranean, Roman and Roman-Jewish-Christian Europe. Running through this development are three prominent themes, known to the ancient historians and in part for this reason emphasized by RLF: freedom, justice and luxury. (TCW, 7) These are not only thematic lenses through which the ancients understood their world; freedom and justice in one way, luxury in another were cardinal political ideals: The Greek victories over barbarian Persians and Carthaginians were certainly related to the three major themes of this book. Both the Carthaginians and the Persians displayed for more riches and luxury than the Greeks in the city-states. They set out to destroy Greek political freedom and if victorious would have substituted their own justice. But luxury was not the main reason why their armies failed. Freedom, rather, was the crucial value in the Greek victories, and its absence as a motivating force was a crucial reason for the failure of the Persians army and the Carthaginians expeditionary force. (TCW, 126; oddly, but perhaps because they are ubiquitous, none of the three words appears in the Index.) RLF makes clear that two of the three, freedom and justice, did not in different times and places have the same meaning while nonetheless retaining their power to influence the contemporary political imagination. At least once, as when during Vespasians rule from 69 - 79:After 71 the word freedom never appeared again on Vespasians coins (TCW, 546); but in the underlying imagination it endured as the name for a constantly disturbing ideal as, in that imagination, its contrary, servitude, subjection, unfreedom, never could have been. In later Roman law humans are said to be born free (Institutes,I.II.2) and freedom defined, at I.III.1, as a natural faculty that each may do as he pleases unless prevented by law (jure) or force. Justice, then, may oppose freedom thought of as absence of restraint but may allow it in that a just order is one in which mutual freedom is protected; thus justice with freedom becomes an ideal opposed to tyranny. The remaining theme in the history of these nine hundred years is power; for it is an history of empire, of attempts by one state to overcome another, of expansion, of colonization and, finally, of the ambiguous growth of European civilization which this passage from Tacitus (Histories 4.7.4) from the chapter on the Effects of Empire (TCW ch.47) nicely illustrates:

There were always kingdoms and wars throughout Gaul until you submitted to our laws. Although we have so often been provoked, the only thing we have imposed on you by rights of victory is what will enable us to keep the peaceEverything else is shared between usIf the Romans were ever driven out may the gods forbid! what else will happen except wars of all peoples, fighting among themselves.

\section{Plus a change...}

The end notes are excellent and include references to authors who differ from RLF on 
the matter in question. The select bibliography is very usefully arranged in that it includes both a list of books and articles referring to the book in general and lists referring to specific chapters. The commentary on the illustrations is valuable. TCW relies on an immense body of scholarship. It is also, as might not have been the case, highly enjoyable, the protagonists are believable men and women, and the authors gently waspish sense of humour now and then breaks through.

Garrett Barden (b. Dublin 1939): He studied in Ireland, Belgium, England and Australia, taught in the US, Ireland, France, Slovakia and Iceland; since retirement in 1999 he is a regular winter visitor to the University of Akureyri; among his writings are Towards Self-Meaning (with PJ McShane,1969), After Principles (1990) and Essays on a Philosophical Interpretation of Justice: the Virtue of Justice (1999). With Tim Murphy of the University of Akureyri, The Grey Goose: an account of law in community, nears completion. 